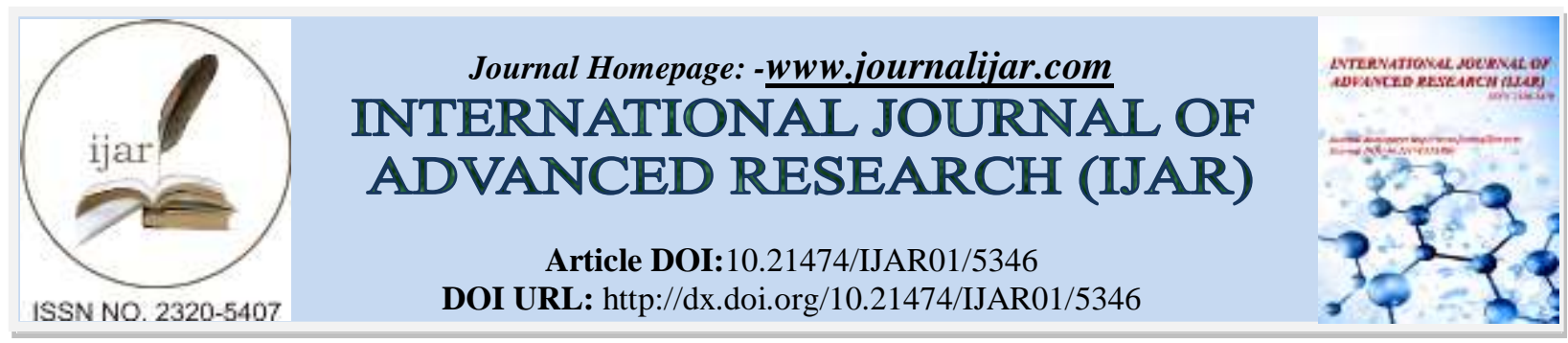

RESEARCH ARTICLE

\title{
EFFECT OF COPPER ON LIPID PEROXIDATION AND ENZYMATIC ANTIOXIDANTS IN SORGHUM BICOLOR.
}

Gosangi avinash.

\section{Manuscript Info}

[.........................

Manuscript History

Received: 07 July 2017

Final Accepted: 09 August 2017

Published: September 2017

Key words:-

Copper; Antioxidant; Antioxidant Enzyme; Ascorbate Peroxidation; GuiacolPeroxidise ; Catalase; Sorghum Bicolor.

\section{Abstract}

Copper $(\mathrm{Cu})$ is one of the micronutrient needed by plants which activates some enzymes in plants, also required in the process of photosynthesis and is essential in plant respiration and assists in metabolism of carbohydrates and proteins. However excess of copper inhibits plant growth and impairs important cellular process (i.e. photosynthesis electron transport). In industrial effluent. Here we reviewed the adverse effects of $\mathrm{Cu}$ on Sorghum bicolor and was investigated. Copper was applied in the form of copper sulphate $\left(\mathrm{CuSo}_{4}, 5 \mathrm{H}_{2} 0\right)$ in four levels $(0,5,10.0$ and $15.0 \mathrm{ppm})$. We observed visible symptoms of $\mathrm{Cu}$ toxicity in this plants. The increased concentrations of $\mathrm{Cu}$ caused oxidative stress in plants and subsequently increased the antioxidant responses due to increased production of highly toxic oxygen free radicals which further increased the defensive mechanisms through Superoxide dismutase (SOD), Ascorbateperoxidise (APX), Guiacolperoxidise (GPX), Catalase (CAT), activites in leaves compared with that of control group.

Copy Right, IJAR, 2017,. All rights reserved.

\section{Introduction:-}

Copper is an essential metal for normal plant growth and development having Atomic number, Density and Weight respectively $29,8.92 \mathrm{~g} / \mathrm{cm}^{3}$ and 63.55 . Copper also occurs naturally in all plants and animals. It is an essential element for all known living organisms including humans and other animals at low levels of intake.In particular, free copper ions can catalyze the formation of highly toxic reactive oxygen species (ROS) such as hydroxyl radicals $\left(\mathrm{OH}^{*}\right)$ from superoxide anions $\left(\mathrm{O}_{2}{ }^{-}\right)$or hydrogen peroxide $\left(\mathrm{H}_{2} \mathrm{O}_{2}\right)$ via the Haber-Weiss reaction. However, in excess, copper can interfere with numerous physiological processes such as enzyme activity, DNA alterations, proteins oxidation, and membrane integrity, all of which could lead to growth inhibition of plant [1].

Plant concentrations of essential elements may exceed the critical the minimum concentrations required for growth and may vary somewhat from species to species. Nonetheless, the following value gives the general requirement of plants. Typical concentrations sufficient for plant growth. Copper $6 \mathrm{mg} / \mathrm{kg}$ relative number of atoms 100.Toxicity to humans: $700-2100 \mathrm{mg} / \mathrm{g}$ dry liver tissue = lethal.

The permissible limit of copper for plants is $10 \mathrm{mg} / \mathrm{kg}$ recommended by WHO[2]. Contamination of drinking water with high level of copper may lead to chronic anaemia. Copper accumulates in liver and brain. Copper toxicity is a fundamental cause of Wilson's disease.Copper particulates are released into the atmosphere by windblown dust; volcanic eruptions; and anthropogenic sources, primarily copper smelters and ore processing facilities. The fate of elemental copper in water is complex and influenced by $\mathrm{pH}$, dissolved oxygen and the presence of oxidizing agents 
and chelating compounds or ions. Concentration of copper in all the soil samples was above the maximum permissible limit set by WHO. Concentration of copper ranged between $0.536-1.504 \mathrm{mg} / \mathrm{kg}$. Copper is an essential trace element in plants and animals, but not some microorganisms. The human body contains copper at a level of about 1.4 to $2.1 \mathrm{mg}$ per $\mathrm{kg}$ of body mass [3].

Toxic levels of $\mathrm{Cu}$ occur naturally in some soils whereas others may contain high levels of $\mathrm{Cu}$ as a result of the anthropogenic release of heavy metals into the environment through mining, smelting, manufacturing, and agriculture waste disposal technologies. At concentrations above those required for optimal growth $\mathrm{Cu}$ was shown to inhibit growth and to interfere with important cellular processes such as photosynthesis and respiration.[4] Hence, the presence of excess $\mathrm{Cu}$ can cause oxidative stress in plants and subsequently increase the antioxidant responses due to increased production of highly toxic oxygen free radicals. Accordingly, it was observed that excess $\mathrm{Cu}$ in plants led to oxidative stress inducing changes in the activity and content of some components of the antioxidative pathways (i.e., ascorbate peroxidase (APX), monodehydroascorbatereductase (MDHAR), dehydroascorbatereductase (DHAR), glutathione reductase (GR), superoxide dismutases (SODs), guiacol peroxidase) [5].Considering that $\mathrm{Cu}$ is an efficient catalyst in the formation of reactive oxygen species (ROS), it was suggested that the increased $\mathrm{Cu}$ toxicity by light during photo inhibition is due to production of hydroxyl radicals [6]. Reactive oxygen species which include superoxide anion radical $\left(\mathrm{O}_{2}\right.$ hydrogen peroxide $\left(\mathrm{H}_{2} \mathrm{O}_{2}\right)$, hydroxyl radical $(\mathrm{OH})$ and singlet oxygen $\left({ }^{1} \mathrm{O}_{2}\right)$ are amongst the most reactive compounds known to be produced during heavy metal stress [7] These protective enzymes include antioxidant enzymes such as superoxide dismutase (SOD), peroxidases like ascorbate (APX) and guiacol (POD) peroxidase. SOD is located in various cell compartments and catalyzes the disproportionation of two $\mathrm{O}_{2}$ radicals to $\mathrm{H}_{2} \mathrm{O}_{2}$ and $\mathrm{O}_{2}$. Ascorbate peroxidase is primarily located in chloroplast and cytosol and it is the key enzymes of the ascorbate glutathione cycle that uses ascorbate as reducing substrate for $\mathrm{H}_{2} \mathrm{O}_{2}$ detoxification. However, hydrogen is also toxic to cells. In plant cells the most important reducing substrate for $\mathrm{H}_{2} \mathrm{O}_{2}$ detoxification is ascorbate [8]

\section{Materials And Methods:-}

Experimental setup and design:-

Sorghum bicolorwere pot cultured in department of biochemistry and biochemical technology SHIATS Allahabad (deemed university) allahabad. Treatment was given with different concentrations of cu i.e. (5.0ppm, 1.0ppm, $15.0 \mathrm{ppm})$ in the form of copper sulphate. Hoagland solution is supplemented as a nutrient solution for every 2 days interwell. Leaves were harvested for every 15 days interwell (3 harvests).

\section{Malondialdehyde (MDA) content:-}

The lipid peroxidation in the plant tissue was measured in terms of malondialdehyde (MDA) content determined by the thiobarbituric acid (TBA) reaction following the method of Health and Packer, 1968 [24]. The plant samples (leaves, $300 \mathrm{mg}$ each) were homogenized in $3 \mathrm{ml}$ of $0.2 \%$, trichloroacetic acid.

\section{Estimation of antioxidants:-}

Plant tissues, leaves (200 mg each) were homogenized in $2 \mathrm{ml}$ of $100 \mathrm{mM}$ potassium phosphate buffer, pH 7.5 containing $1 \mathrm{mM}$ of EDTA in presence of pinch of polyvinyl polypyrrolidone (PVP). The homogenate was centrifuged at $10000 \mathrm{~g}$ for $15 \mathrm{~min}$ at $4^{\circ} \mathrm{C}$. All steps in the preparation of enzyme extract were carried out at $0-4^{\circ} \mathrm{C}$. This supernatant was used to measure the activities of superoxide dismutase, ascorbate peroxidase and guiacol peroxidase.

\section{Superoxide dismutase (EC 1.15.1.1):-}

The assay system for superoxide dismutase was adopted from the method of Nishikimi and Rao, 1972 [25] and activity was expressed as units per $\mathrm{g}$ fw. Assay mixture contained $1.2 \mathrm{ml}$ sodium pyrophosphate buffer (pH 8.3 , $0.052 \mathrm{M}$ ), $0.1 \mathrm{ml} 186 \mu$ Mphenazinemethosulphate, $0.3 \mathrm{ml} 300 \mu$ Mnitrobluetetrazolium, $0.2 \mathrm{ml}$ NADH (780 $\mu \mathrm{M}), 50$ $\mu \mathrm{l}$ plant extract and water $(1.15 \mathrm{ml})$ in a total volume of $3 \mathrm{ml}$.

\section{Ascorbate peroxidase (EC 1.11.1.11):-}

The activity of ascorbate peroxidase was measured of the method of Nakano and Asada, 1981 [26] by estimating the rate of ascorbate oxidation at $290 \mathrm{~nm}$. Enzyme activity was calculated in terms of $\mu$ mol of ascorbate oxidized min-1 g-1 fresh weight at $25 \pm 2^{\circ} \mathrm{C}$. 
Guiacol peroxidase (EC 1.11.1.7):-

Guiacol peroxidase was measured in plant parts, following the method of Curtis, 1971[27], modified by Kato and Shimizu, 1987 [28]. Activity was calculated using the extinction coefficient of $26.6 \mathrm{mM}-1 \mathrm{~cm}-1$ at $470 \mathrm{~nm}$ for oxidized tetraguiacol polymer. One unit of peroxidase activity was defined as the calculated consumption of $1 \mu \mathrm{mol}$ of $\mathrm{H} 2 \mathrm{O} 2$ min-1 g-1 fresh weight.

\section{Chlorophyll and carotenoid content:-}

Plant tissues, leaves $(200 \mathrm{mg})$ were crushed in $5 \mathrm{ml}$ of $(80 \%$, v/v) chilled acetone by the method of Arnon, 1949; Duxbury and Yentsch, 1956 [29,30]. Extract was centrifuged at 10,000 g for $10 \mathrm{~min}$ and absorbance of the supernatant was read at 510 and $480 \mathrm{~nm}$ using GBC Cintra 10e UV-VIS Spectrophotometer. Carotenoid content was calculated in mg g-1 fw by the formula as given below (Duxbury and Yentsch, 1956) [31].

Carotenoid $(\mathrm{mg} \mathrm{g}-1 \mathrm{fw})=[[7.6(\mathrm{~A} 480)-2.63(\mathrm{~A} 510)] \mathrm{x} \mathrm{V}] / 1000 \times \mathrm{W}$

Where:

A510 and A480 $=$ Absorption at the

\section{Protein content:-}

Protein was estimated by the method of Lowry et al. [32], using BSA as a standard protein, is a globular protein of molecular weight 68,000 . Leaves $(100 \mathrm{mg})$ of treated and control plants were crushed in $3 \mathrm{ml}$ of $10 \%$ chilled tricholoracetic acid (TCA) and centrifuged at $10,000 \mathrm{~g}$ for $10 \mathrm{~min}$ and then last, the absorbance was recorded at 660 nm using bovine serum albumin (BSA) as a standard.

\section{Activity of MDA:-}

The results were compared between different exposure periods, which showed increased in MDA content of in the leaves as $29.038 \%, 63.12 \%$ and $40.63 \%$ after $1^{\text {st }} 2^{\text {nd }}$ and $3^{\text {rd }}$ harvest respectively when compared to control. MDA is the by-product of lipid per oxidation was considerably increased by heavy metals, which was also reported by (Gallegoet al., 1996). According to (Sarmishtadeyet al., 2015) the increase in the concentration of cu, the MDA content increased and showed a significant positive correlation with cu concentration .This shows that high concentration of cu can lead to lipid per oxidation which causes damage to the balance of ROS scavenging activities in the experiment copper-induced changes in growth and antioxidative mechanisms of tea plant Camellia Sinensis (L.). Lipid per oxidation in roots of seedlings may be due to membrane degeneration This result supports the possibility that the increase in peroxidation is due to the inhibition of ROS or by the enzyme lipoxygenase that are activated under metal stress (Dietz $\boldsymbol{e t}$ al., 1999).Showed that $\mathrm{Cd}$ causes an enhanced lipid peroxidation and consequently degradation of chlorophyll by lipid peroxides.

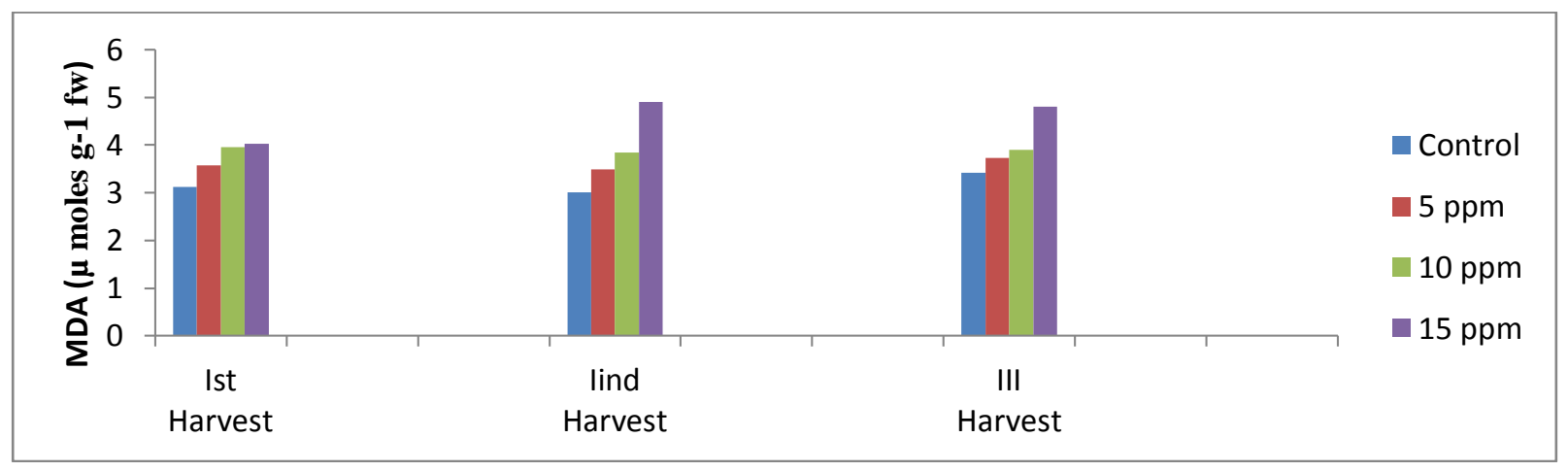

Activity of Superoxide dismutase:-

Superoxide dismutase is the first antioxidant enzyme to deal with oxyradicals by accelerating the dismutation of superoxide (O2-) to hydrogen peroxide (H2O2). Thus, SOD acts supportive antioxidative enzyme which provide protective defense against reactive oxygen species (Mansor, 2009). In the present study, specific activity of SOD expressed higher at $10 \mathrm{ppm} \mathrm{Cu}$ treated plants $\left(14.58 \%, 1^{\text {st }}\right.$ harvest $),\left(14.60 \%, 2^{\text {nd }}\right.$ harvest $)$ and $\left(16.25 \%, 3^{\text {rd }}\right.$ harvest $)$ as compared to control shown in figure 5.2 table 5.2 .According to S.Gaoet al., (2008) excess of copper increases SOD activity in the experiment Effects of copper on growth, antioxidant enzymes and phenylalanine ammonialyaseactivitiesinJatrophacurcas L. seedling. The SOD activity of a plant is increased by the use of high concentration of heavy metal ions, by an increase in $\mathrm{SO}_{2}$ concentration (Ashraf et al., 2009). A generalplant 
response to stress in activation of the system of antioxidative defense, which prevents each cell components from oxidative injury. One of the cell responses to the increased metal concentration in the environment is the increase in the capacity of antioxidative enzymes such as POD, SOD, and CAT (Vangronsveld and Clijsters, 1994. The changes of antioxidative enzymes level in a plant depends on duration of plant exposure to the metal stress and on metal concentration.



Figure5.2:-Effect of $\mathrm{Cu}$ on the SOD content $\left(\mu \mathrm{min}^{-1} \mathrm{~g}^{-1} \mathrm{fw}\right.$ ) of the Sorghum bicolor Leaves (on $15^{\mathrm{th}} 30^{\mathrm{th}}$ and $45^{\mathrm{th}}$

Activity of APX:-

days from day of germination).

There was an increasing trend in ascorbate peroxidase activity when subjected to different concentration $\mathrm{Cu}$ stress treatments. Ascorbate peroxidase activity increased to the maximum when the subjected to $5.0 \mathrm{ppm} \mathrm{Cu}(39.41 \%$,at $1^{\text {st }}$ harvest), $\left(37.69 \%\right.$ at $2^{\text {nd }}$ harvest) and $\left(37.78 \%\right.$ at $3^{\text {rd }}$ harvest) as compared to control. Sarmishtaet al,.(2014) also reported that there was a significant increase in the APX activity in the initial level of treatment with $200 \mu \mathrm{M}, 300$ $\mu \mathrm{M}$ of cu respectively but there was a slight decrease in the APX activity with $600 \mu \mathrm{M}$ cu treatment. which supports this current research.APX: Recent studies have focused on the changes in activity of APX in higher plants subjected to several environmental stresses such as ozone, high lights, extremes of temperature, salts, heavy metals etc (Yoshimura et al., 2000). APX activities generally increased along with activities of other ant oxidative enzymes like CAT, SOD, GPOD and GR in response to heavy metal stress factors, suggesting that the component of ROS scavengers are co-regulated. APX is a component of ascorbate-glutathione pathway, which plays a role in scavenging $\mathrm{H}_{2} \mathrm{O}_{2}$ because it is a systemic signal for the induction of APX (Morita $\boldsymbol{e t}$ al., 1999). In well agreement with the results presented in this work, Hegedusetal., (2001) found that activities of APX were increased in roots and leaves of barley and bean plants.

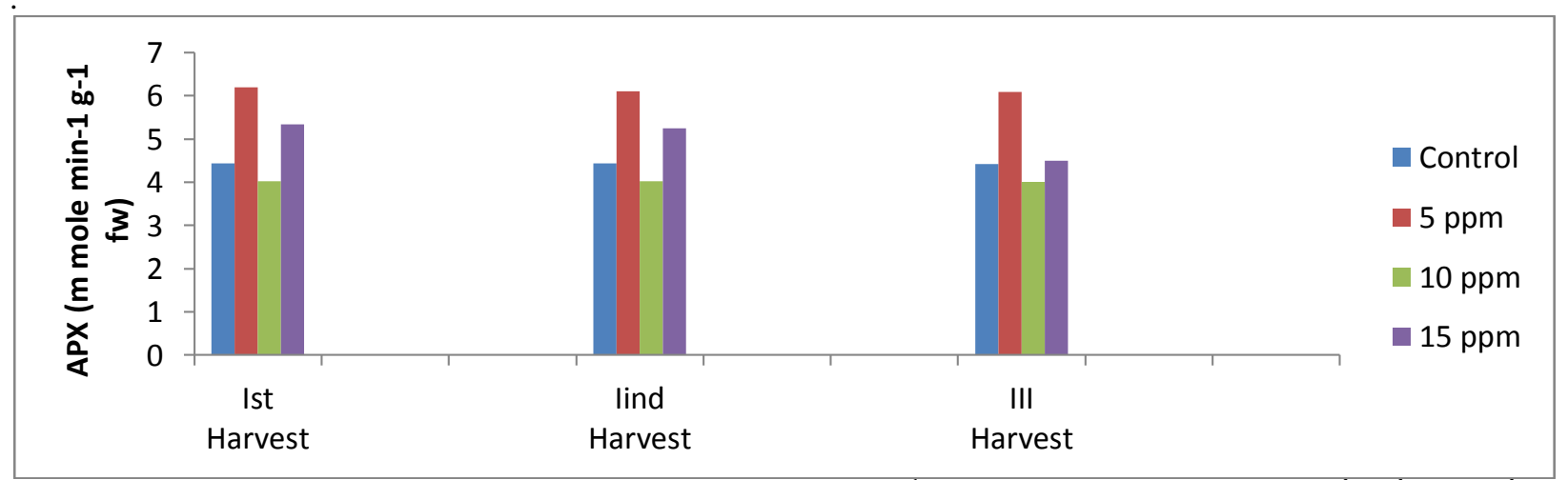

Figure 5. 3:-The effect of $\mathrm{Cu}$ on APX content in leaf $\left(\mu\right.$ moles $\mathrm{g}^{-1}$ fw) of Sorghum bicolor. (on $15^{\text {th, }} 30^{\text {th }}$ and $45^{\text {th }}$ days from day of germination).

\section{Activity of GPX :-}

The concentration wise analysis of the data of guiacol peroxidase activity in the leaves showed reduction with increasing $\mathrm{Cu}$ concentration as compound to control. The maximum increase of $\left(45.23 \%\right.$ at $1^{\text {st }}$ harvest $)$, (29.31\%, at $2^{\text {nd }}$ harvest) and $\left(36.31 \%\right.$ at $3^{\text {rd }}$ harvest $)$ at $10.0 \mathrm{ppm}$ concentration of $\mathrm{Cu}$ as compared to control shown in figure $\mathbf{5 . 3}$ and table5.3 The induction of a particular group of enzyme activities is considered to play an important role in the cellular defence strategy against oxidative stress, caused by toxic metals concentratios Clijsterset al.,(1994). According to Thorny et al., (2012) GPX activity has been increased with increasing copper concentration in the 
experiment Excess copper induced oxidative stress and response of antioxidants in rice. An increase in the GPX activity was found in the leaves. Sinhaet al.,(1997). : Induction in GPOD activity has been documented under a variety of stressful condition under toxic levels of $\mathrm{Al}, \mathrm{Cu}, \mathrm{Cd}, \mathrm{Zn}$ ( Chaouiet al .,1997). As GPOD are located in cytosol, cell wall, vacuole and in extracellular spaces, increased peroxidase activity in Pb stressed seedlings, might be possibly due to increased release of peroxidases localized in the cell walls. Under sublethal salinity and metal toxicity conditions, level of peroxidase activity has been used as potential biomarker to evaluate the intensity of stress (Shah et al., 2001).

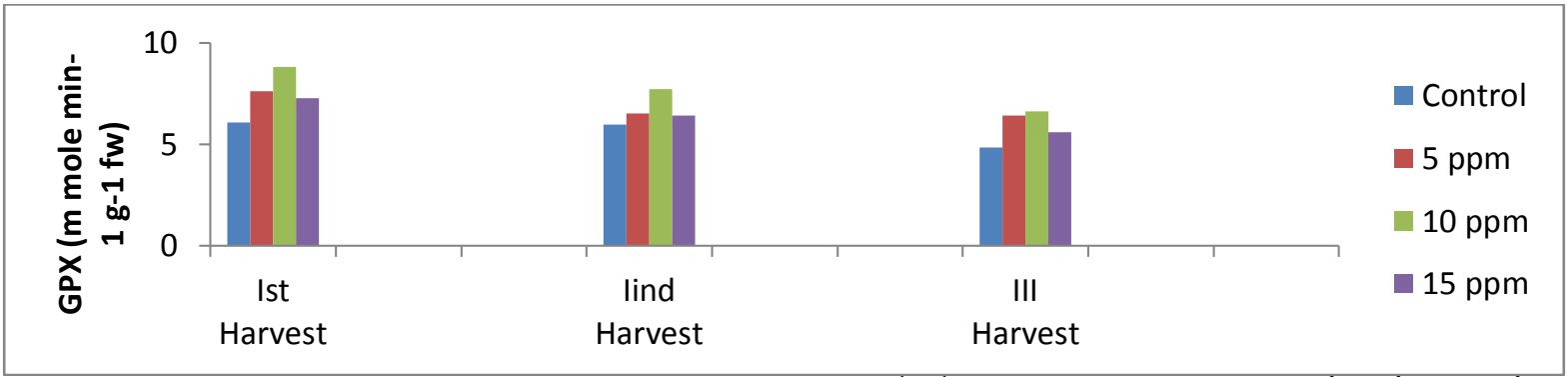

Figure 5. 4:-The effects of $\mathrm{Cu}$ on the GPX content $\left(\mu \mathrm{mol} \mathrm{min} \mathrm{g}^{-1} \mathrm{~g}^{-1} \mathrm{fw}\right)$ in Sorghum bicolor $\left(15^{\text {th, }} 30^{\text {th }}\right.$ and $45^{\text {th }}$ days from day of germination).

\section{Activity of Catalase:-}

Catalase is a peroxisomalheme protein that catalyses the removal of hydrogen peroxide formed during the reaction catalysed by SOD. Thus, CAT acts supportive antioxidative enzyme which provide protective defense against reactive oxygen species (Mansor, 2009). The concentration wise analysis of the data of catalase activity in the leaves showed increase in activity with increasing cu concentration as compared to control. The maximum increase of $70.21 \%, 71.11 \%$ and $72.92 \%$ for $1^{\text {st }}, 2^{\text {nd }}$ and $3^{\text {rd }}$ harvest respectively at $10 \mathrm{ppm}$ concentration of cu was observed at days as compared to control as shown in figure 5.5 and table 5.5.CAT works more effectively at scavenging the $\mathrm{H}_{2} \mathrm{O}_{2}$ converting it into oxygen and water $\mathbf{L i}$ et al.,(2004) According to Gaoet al.,(2008) excess of copper increases CAT activity in the experiment Effects of copper on growth, antioxidant enzymes and phenylalanine ammonia-lyase activities inJatrophacurcas L. seedling. Activity of CATwas examined as one of the major antioxidant enzyme that eliminates $\mathrm{H}_{2} \mathrm{O}_{2}$. by converting it into oxygen and water (Foyer and Noctor, 2000). Activity of CAT in response to Cr has been studied in many crop plants like rice, wheat, green gram and even in lower plants like mosses (Choudhury and panda, 2004). In rice, $\mathrm{Cr}$ can either induce CAT activity or suppress it. Treatment of developing wheat seedlings of different concentrations of $\mathrm{Cr}$ showed varied response.

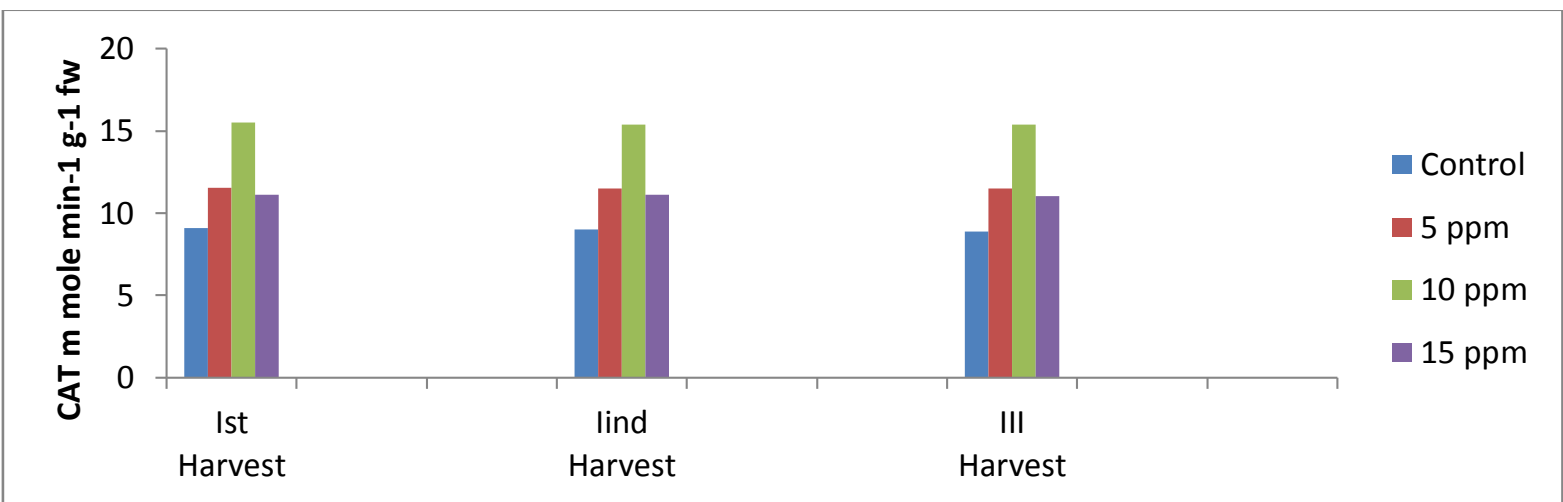

Figure 5. 5:-The effect of $\mathrm{Cu}$ on the catalase activity $\left(\mu \mathrm{mol} \mathrm{min} \mathrm{m}^{-1} \mathrm{~g}^{-1} \mathrm{fw}\right)$ in Sorghum $\quad$ bicolor. $\left(\right.$ on $15^{\text {th }}, 30^{\text {th }}$ and

Protein Content:-

$45^{\text {th }}$ days from day of germination).

Data presented in table no 5.6 and figure no 5.6indicates that in leaves, protein content showed decrease at all concentration and maximum decrease was observed as $\mathrm{s} 44.13 \%, 44.4 \%$ and $40.74 \%$ after $1^{\text {st }}, 2^{\text {nd }}$, and 3 rdharvest respectively at $15.0 \mathrm{ppm}$. The results were compared between different exposure periods, which showed decrease in protein content of in the leaves at all the concentration as compared to control. According to (GUO et al., 2007) the high levels of cu induced the reduction in leaf total soluble protein in barley plants.The mechanism by which copper 
affects protein content is complex and needs a further study. Heavy metals induce the synthesis of stress proteins, which might limit and repair the damages caused by metals to cell proteins and exert protective effects on membranes (Sanita di Toppi and Gabbrielli,1999).

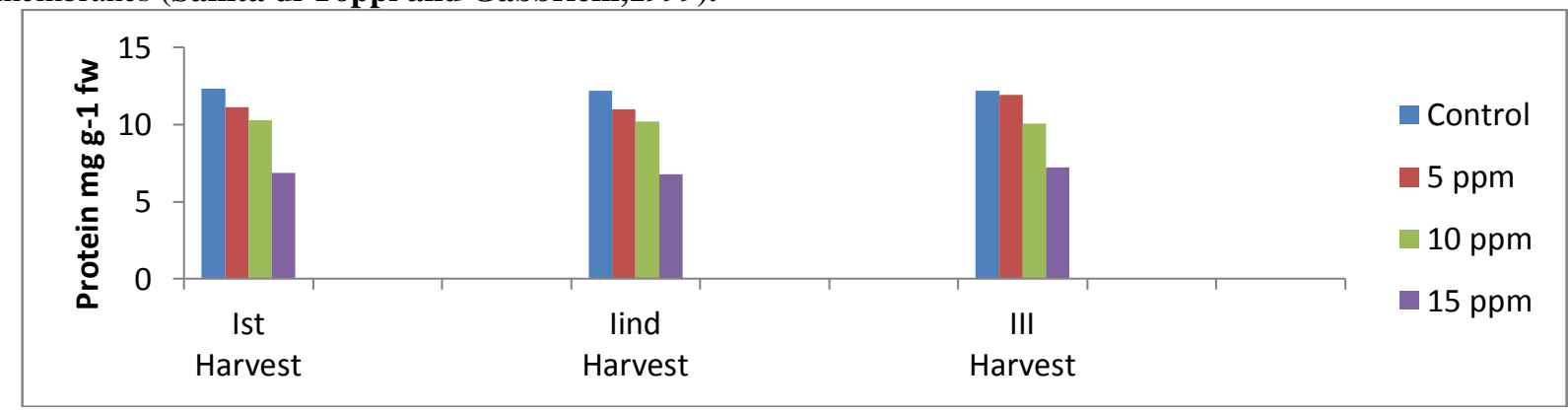

Effect of the Copper on Chlorophyll a, b, and total Chlorophyll content in Sorghum bicolor (L.) leaves:-

The concentration scrutiny of the data demonstrated decrease in chlorophyll a, b, and total chlorophyll content in the leaves, with increasing concentration of $\mathrm{Cu}$ upto $15.0 \mathrm{ppm}$ after 15 days from sowing as compared to control. The maximum decrease of 55.68\%, 64.12\% and $70.06 \%$ was observed at $15 \mathrm{ppm}$ concentration of $\mathrm{Cu}$ after the exposure period respectively in first harvest. However, during days of exposure period, the chlorophyll a, b and total chlorophyll content was found to decrease with increase in concentration of $\mathrm{Cu}$. Maximum decrease of 51.36\%, $52.29 \%$ and $55.71 \%$ was observed at $15.0 \mathrm{ppm}$ after 30days $\left(2^{\text {nd }}\right.$ harvest $)$ of exposure as compared to respective control. A decrease in chlorophyll content was found to be significant on increasing copper concentration .This observation was also supported by Chandra and Alam, (2013) in the study copper scavenging potential and its effect on chlorophyll in seedlings of Brassica juncea $(L$.)The decrease in chlorophyll content may be due to reduced chlorophyll biosynthesis by inhibiting $\delta$-amino levulinic dehydrogenase and protochlorophyllidereductase activities and breakdown of pigments or their precursor as reported by Teramura and Sullivan in 1994.

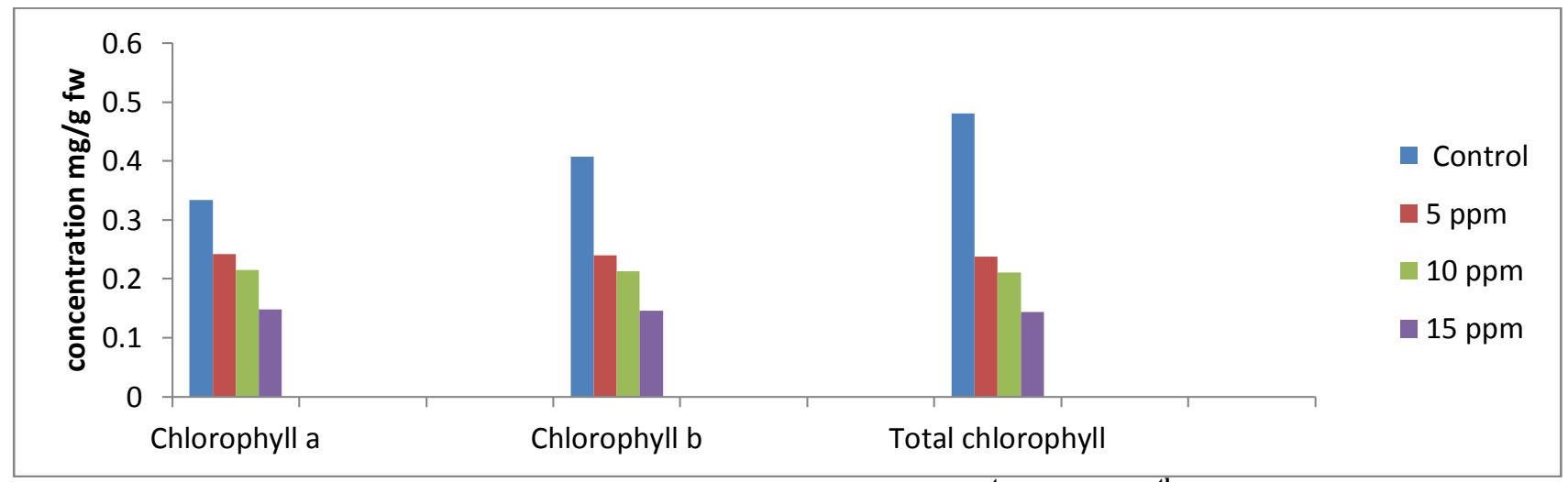

Effect of Cu on Chlorophyll content in Sorghum bicolor Leaves $\left(1^{\text {st }}\right.$ harvest; $15^{\text {th }}$ days from day of germination)

\section{References:-}

1. Heath RL, Packer L (1968)Photoperoxidation in isolated chloroplasts. I. Kinetics and stoichiometry of fatty acid peroxidation. Arch BiochemBiophys 125: 189-198.

2. Alaoui S.B., Genet P., DunandV.F., Toussaint M.L., Epron D. andBadot P.M. (2004): Effect of copper on growth in cucumber plants (Cucumissativus) and its relationships with carbohydrate accumulation and changes in ion contents. Plant Sci. 166:1213-1218.

3. Zaigham Hassan, Zubair Anwar, Khalid UsmanKhattak, Mazhar Islam, RizwanUllah Khan , JabarZaman Khan Khattak; et al., (2012): Civic Pollution and Its Effect on Water Quality of River Toi at District Kohat, NWFP Research Journal of Environmental andEarth Sciences, $\mathbf{4 , 5}$

4. AdelsteinS. J.,Vallee B. L., M.D.N Engl. and J Med. (1961):Copper Metabolism in Man265:892-897.

5. De Vos C.H.R., Vonk M.J., VooijsR.andSchat H. (1992): Glutathione depletion due to copper-induced phytochelatin synthesis causes oxidative stress in Silenecucubalus. Plant Physiology98:853-858. 
6. Taramura, A. H. and Sullivan, J. H. (1994): Effect of UV-B Radiation on photosysthesis and growth of terrestrial plants. Photostnth. Res. 39:463-473.

7. Gallego, S. M.; Benavides, M. P. and Tomaro, M. L. (1996): Effect of heay metal ion excess on sunflower leaves: evidence for involvement of oxidative stress. Plant Sci.121: 151-159.

8. Sarmishta D., Mazumder1 P.B. and Paul S.B. (2015): Copper-induced changes in growth and antioxidative mechanisms of tea plant (Camellia sinensis(L.) O. Kuntze)

9. Dietz K. J.; Baier, M. and Kramer, U. (1999): Free radical and reactive oxygen species as mediaters of heavy metal toxicity in plants. In:Prasad, M. N. V., Hagemeyer, J (eds), Heavy metal stress in plants: from molecules of ecosystems, pp-73-97. Springer-Verlag, Berlin.

10. DayangkuDalilahMamat ., Chun Shiong Chong., AzmanAbdSamad ., Tsun Thai Chai., FazilahAbdManan. (2015): Effects of copper on total phenolics, flavonoids and mitochondrial properties of Orthosiphonstamineus callus culture International Journal of Agriculture and Biology17:12431248

11. Heath RL, Packer L (1968)Photoperoxidation in isolated chloroplasts. I. Kinetics and stoichiometry of fattsssy acid peroxidation. Arch BiochemBiophys 125: 189-198.

12. Nishikimi M, Appaji N, Yagi K (1972)The occurrence of superoxide anion in the reaction of reduced phenazinemethosulfate and molecular oxygen. BiochemBiophys Res Commun 46: 849-854.

13. Nakano Y, Asada K (1981) Hydrogen peroxide is scavenged by ascorbate-specific peroxidase in spinach chloroplasts. Plant Cell Physiol 22: 867-880.

14. Curtis CR (1971) Disc electrophoretic comparison of proteins and peroxidases from Phaseolus vulgaris infected with Agrobacterium tumefaciens. Can J Botany 49: 333-337.

15. Arnon DI (1949) Copper enzymes in isolated chloroplasts. Polyphenoloxidase in beta vulgaris. Plant Physiol 24: 1-15.

16. Duxbury AC, Yentsch CS (1956) Plankton pigment monograph. J Mar Res 1: 92-101.

17. Guo T.R., Girotto E., Ceretta C.A., Rossato L.V., Farias J.G., Tiecher T.L., Conti L., Schmatz R., ZHANG G.P. AND ZHANG Y.H. (2007): PHYSIOLOGICAL CHANGES IN BARLEY PLANTS UNDER COMBINED TOXICITY OF ALUMINUM, COPPER AND CADMIUM. COLLOIDS SURF. B BIOINTERFACES.57: 182-188.

18. Sanitadi Toppi, L. and Gabbrielli, R. (1999): Response to cadmium in higher plants. Environ. Exp. Bot. 41:105-130.

19. Fikriyekirbagzengin and omermunzuroglu.(2005):effects of some heavy metals on content ofchlorophyll, proline and some antioxidant chemicalsin bean (phaseolus vulgaris 1.) Seedlingsactabiologicacracoviensia series botanica 47/2: 157-164

20. Prakash, V.; Mishra, P. K. and Mishra, M. (2009): Screening of medical plant extract for antioxidant activity. J. Medicinal Plants Res.3: 608-612.

21. Smirnoff, N. (2000): Ascorbic acid: metabolism and function of a multifaceted molecule. Curr. Opin. Plant. Biol. 3: 229-235.

22. Li X., Ma H., Jia P., Wang J., Jia L., Zhang T., Yang Y., Chen H. and Wei X. (2012): Responses of seedling growth and antioxidant activity to excess iron and copper in TriticumaestivumL.EcotoxicolEnvironSaf .86:47-53. 